\title{
SUPERVISI AKADEMIK PADA PENINGKATAN KEMAMPUAN GURU DALAM MENYUSUN RENCANA PELAKSANAAN PEMBELAJARAN (RPP)
}

\author{
SUKIRNO \\ Kepala SMK Negeri 2 Sarolangun Provinsi Jambi \\ e-mail : sukrinosmk1clp@gmail.com
}

\begin{abstract}
ABSTRAK
Berdasarkan hasil evaluasi diri sekolah dan supervisi yang dilakukan terhadap guru di SMK Negeri 2 Sarolangun Provinsi Jambi, ditemukan bahwa kemampuan guru dalam menyusun RPP masih rendah. Tujuan penelitian ini untuk mendeskripsikan dan mendapatkan informasi tentang upaya meningkatkan Kompetensi Guru dalam menyusun RPP melalui Supervisi akademik di SMK Negeri 2 Sarolangun. Penelitian ini merupakan penelitian tindakan sekolah (School Action Research). Prosedur penelitian dalam penelitian ini meliputi perencanaan, tindakan, obeservasi dan refleksi. Penelitian ini terdiri dari dua siklus dengan empat kali pertemuan. Subjek penelitian terdiri dari 30 orang guru di SMK Negeri 2 Sarolangun. Data penelitian dikumpulkan dengan menggunakan instrument penilaian. Berdasarkan hasil penelitian dapat disimpulkan bahwa melalui supervisi akademik dapat meningkatkan Kompetensi Guru dalam menyusun Rencana Pelaksanaa Pembelajaran di SMK Negeri 2 Sarolangun. Hal ini dilihat dari kesiapan guru dalam pelaksanaan pembelajaran. Disamping itu berdasarkan hasil penilitian yang dilakukan nilai rata-rata RPP yang dibuat oleh guru juga mengalami peningkatan yaitu pada siklus 1 rata- rata nilai 70,10 dan pada siklus 2 dengan nilai rata-rata 80,5.
\end{abstract}

Kata Kunci: Supervisi Akademik, Kompetensi Guru, Menyusun RPP

\section{PENDAHULUAN}

Sesuai dengan Undang-undang No. 20 Tahun 2003 tentang Sistem Pendidikan Nasional, jabatan guru sebagai pendidik merupakan jabatan professional. Guru yang profesional adalah orang yang memilki kemapuan atau keahlian khusus dalam bidan keguruan (pembelajaran) sehingga ia mampu melakukan tugas dan fungsinya sebagai seorang pembelajar dengan kemampuan maksimal. Rendahnya kompetensi guru dalam menyusun Rencana Pelaksanaan Pembelajaran (RPP) ini disebabkan berbagai macam faktor. Dari hasil wawancara dan tanya jawab kepada guru, hal tersebut disebabkan karena terlalu banyak syarat administrasi sehingga untuk mencari jalan yang praktis. Di satu sisi, sementara informasi yang diterima lewat pendidikan dan pelatihan belum tuntas secara mendalam sehingga pemahaman materi masih mengambang. kesibukan pribadi di luar kedinasan tidak bisa di tinggalkan sehingga tidak ada kesempatan untuk mempelajari sendiri di rumah. Hal tersebut bisa menjadi pemicu kekurangprofesionalan yang bersangkutan dalam mengerjakan profesi. Sudjana (2008).

Upaya memperbaiki dan meningkatkan mutu pendidikan seakan tidak pernah berhenti. Reformasi pendidikan tidak cukup hanya dengan perubahan dalam sektor kurikulum, baik struktur maupun prosedur penulisannya. Pembaharuan kurikulum akan lebih bermakna bila diikuti oleh perubahan praktik pembelajaran di dalam maupun di luar kelas. Keberhasilan implementasi kurikulum sangat dipengaruhi oleh kemampuan guru yang akan menerapkan dan mengaktualisasikan kurikulum tersebut. Tidak jarang kegagalan implementasi kurikulum disebabkan oleh kurangnya pengetahuan, keterampilan dan kemampuan guru dalam memahami tugas tugas yang harus dilaksanakannya. Hal itu berarti bahwa guru sebagai pelaksana kegiatan pembelajaran menjadi kunci atas keterlaksanaan kurikulum di sekolah. Mulyasa (2011: 37) menyatakan bahwa, "Tugas guru untuk menjadi guru profesional meliputi, mendidik, mengajar, dan melatih". Mendidik berarti meneruskan dan mengembangkan nilai nilai hidup.

Mencermati uraian di atas, terlihat betapa besarnya peran guru dalam membantu pertumbuhan dan perkembangan peserta didik. Guru memiliki peran dan fungsi yang sangat penting dalam membentuk kepribadian, akhlak, mentalitas, dan moral anak. Dengan demikian dapat dikatakan tercapainya tujuan pendidikan di sekolah sangat dipengaruhi oleh sikap guru 
dalam melaksanakan tugas profesinya. Dalam kurikulum 2013, guru tidak perlu membuat sendiri silabus karena sudah dipersiapkan dari pemerintah, namun sebagai seorang guru tisak lepas dari fungsi administrasi. Dalam kaitannnya dengan fungsi administrasi ini, lebih spesifik dalam hal proses belajar mengajar, Gagne dan Berliner dalam Makmun (2005: 23) mengemukakan tiga fungsi atau peran guru dalam proses tersebut, yaitu sebagai : 1) Perencana (planner) yang harus mempersiapkan apa yang harus dilakukan di dalam proses belajarmengajar (pre-teaching problems). 2) Pelaksana (organizer) yang harus menciptakan situasi, memimpin, merangsang, menggerakkan, dan mengarahkan kegiatan belajar mengajar sesuai dengan rencana, bertindak sebagai nara sumber (source person), konsultan kepemimpinan (leader), yang bijaksana dalam arti demokratis dan humanistik (manusiawi) selama proses berlangsung (during teaching problems). 3) Penilai (evaluator) yang harus mengumpulkan, menganalisis, menafsirkan dan akhirnya harus memberikan pertimbangan (judgement) atas tingkat keberhasilan belajar mengajar tersebut berdasarkan kriteria yang ditetapkan baik mengenai aspek keefektifan prosesnya, maupun kualifikasi produk (output)nya. Sementara itu secara adminstrasi kepala sekolah mempunyai tugas sebagai supervisor yang tugasnya membimbing kesulitan guru. Hal ini sesuai pernyataan (Glickman, at al: 2007) yang menyatakan bahwa Salah satu tugas kepala sekolah adalah melaksanakan supervisi akademik. Untuk melaksanakannya secara efektif, diperlukan keterampilan konseptual, interpersonal dan teknikal Menyoroti salah satu peran guru dalam proses pembelajaran, yaitu sebagai perencana pembelajaran, setiap guru pada satuan pendidikan berkewajiban menyusun RPP yang lengkap dan sistematis agar pembelajaran efektif dan bermutu. Pembelajaran yang berlangsung secara efektif dan bermutu akan berimplikasi pada peningkatan mutu proses dan hasil belajar peserta didik.

Perencanaan pembelajaran merupakan langkah yang sangat penting sebelum pelaksanaan pembelajaran. Perencanaan yang matang diperlukan supaya pelaksanaan pembelajaran berjalan secara efektif. Perencanaan pembelajaran dituangkan ke dalam Rencana Pelaksanaan Pembelajaran (RPP). RPP memuat Kompetensi Inti (KI) kompetensi Dasar (KD), indikator yang akan dicapai, materi yang akan dipelajari, metode pembelajaran, langkah pembelajaran, media pembelajaran, dan sumber belajar serta penilaian. Guru pada satuan pendidikan berkewajiban menyusun RPP secara lengkap dan sistematis agar pembelajaran berlangsung secara interaktif, inspiratif, menyenangkan, menantang, memotivasi peserta didik untuk berpartisipasi aktif, serta memberikan ruang yang cukup bagi prakarsa, kreativitas, dan kemandirian sesuai dengan bakat, minat dan perkembangan fisik serta psikologis peserta didik. Upaya perwujudan pengembangan silabus menjadi perencanaan pembelajaran yang implementatif memerlukan kemampuan yang komprehensif. Kemampuan itulah yang dapat mengantarkan guru menjadi tenaga yang professional. Guru yang professional harus memiliki 5 (lima) kompetensi yang salah satunya adalah kompetensi penyusunan rencana pembelajaran. Namun dalam kenyataannya masih banyak guru yang belum mampu menyusun rencana, sebagian guru tidak membuat sendiri silabus dan RPP mata pelajaran yang diampu sehingga hal ini secara otomatis berimbas pada kualitas pembelajaran. Berdasarkan hal-hal tersebut peneliti mengadakan sebuah penelitian tindakan sekolah dengan judul "Peningkatan Kompetensi Guru Dalam Menyusun Rencana Pelaksanaan Pembelajaran Melalui Supervisi Akademik Di SMK Negeri 2 Sarolangun Provinsi Jambi”.

\section{METODE PENELITIAN}

Penelitian yang dilakukan ini adalah penelitian tindakan. Menurut Zuriah, (2003:54) penelitian tindakan menekankan kepada kegiatan (tindakan) dengan mengujicobakan suatu ide ke dalam praktek atau situasi nyata dalam skala mikro yang diharapkan kegiatan tersebut mampu memperbaiki, meningkatkan kualitas dan melakukan perbaikan sosial. Penelitian tindakan yang dilakukan adalah penelitian tindakan sekolah (PTS).

Penelitian tindakan sekolah ini dilakukan di SMK Negeri 2 Sarolangun Provinsi Jambi, dilakukan dalam dua siklus, masing-masing siklus terdiri atas empat tahapan dalam tiap 
siklusnya. Diantaranya: 1) perencanaan, 2) tindakan, 3) observer, dan 4) refleksi. Model penelitian tindakan yang digunakan adalah model Stephen Kemmis dan Mc. Taggart. Mengadopsi dari Semiawan $(1985 ; 49)$ model ini menggunakan sistem spiral yang dimulai dari rencana, tindakan, pengamatan, refleksi dan perencanaan kembali yang merupakan dasar untuk suatu ancangancang pemecahan masalah. Peneliti menggunakan model ini karena dianggap paling praktis dan aktual. Menurut Arikunto (2010: 203) "Instrumen penelitian adalah alat atau fasilitas yang digunakan oleh peneliti dalam mengumpulkan data agar pekerjaannya lebih mudah dan hasilnya lebih baik, dalam arti lebih cermat, lengkap, dan sistematis sehingga lebih mudah diolah".

Untuk mengetahui keefektifan suatu metode dalam kegiatan pembelajaran perlu diadakan analisa data. Pada penelitian ini menggunakan teknik analisis deskriptif kualitatif, yaitu suatu metode penelitian yang bersifat menggambarkan kenyataan atau fakta sesuai dengan data yang diperoleh. Untuk melihat kemampuan guru dari suatu pertemuan ke pertemuan selanjutnya, dan dari siklus I ke siklus II digunakan persentase. Adapun kriteria penilaian sebagai seperti dalam Tabel 1 berikut:

Tabel 1. Kriteria Penilaian RPP Yang Dibuat Guru

\begin{tabular}{rll}
\hline Angka & Huruf & Kriteria \\
\hline $86-100$ & A & Sangat baik \\
\hline $71-85$ & B & Baik \\
\hline $56-70$ & C & Cukup \\
\hline$<55$ & D & Kurang \\
\hline
\end{tabular}

Jika dalam perhitungan secara klasikal yang mendapatkan nilai 71 ke atas (minmal baik) kurang dari $85 \%$, mka dilanjutkan ke siklus kedua.

\section{HASIL DAN PEMBAHASAN}

\section{Siklus 1}

Hasil penelitian tindakan yang dilakukan kepada 30 orang guru di SMK Negeri 2 Sarolangun pada semester genap pada tahun pelajaran 2019/2020. Penelitian ini dilaksanakan dalam dua siklus. Hasil dari penelitian pada siklus 1 akan menjadi tolak ukur perubahan dan perbaikan yang sesuai terhadap proses dan teknik yang akan diterapkan pada siklus II. Berikut ini adalah hasil deskripsi dari guru yang telah membuat RPP sesuai dengan standar penulisan RPP.

Tabel 2. Perolehan Nilai Penyususnan RPP Siklus 1

\begin{tabular}{|c|c|c|c|c|}
\hline No & Nilai & Kriteria & Jumlah & Persentase $(\%)$ \\
\hline 1 & $86-100$ & A & 3 & 10 \\
\hline 2 & $71-85$ & $\mathrm{~B}$ & 15 & 50 \\
\hline 3 & $56-70$ & $\mathrm{C}$ & 12 & 40 \\
\hline 4 & $<55$ & $\mathrm{D}$ & - & - \\
\hline \multicolumn{3}{|c|}{ Jumlah } & 30 & 100 \\
\hline
\end{tabular}

Dari Tabel 2 di atas dapat dijelaskan bahwa dari 30 guru yang mendapatkan nilai baik dalam penyusunan RPP berjumlah 18 orang atau $60 \%$ dan nilai rata-ratanya 70,1. Dari hasil penilaian siklus 1 ini, karena secara klasikal lebih rendah $85 \%$ (dari kriteria yang ditetapkan), maka perlu perbaikan pada siklus 2. Masih rendahnya perolehan nilai dari RPP yang di buat guru dikarenakan RPP yang disusun guru belum lengkap, guru belum seluruhnya memahami dalam pemilihan metode dan model pembelajaran yang dituliskan dalam RPP yang disusun, 
guru belum menuliskan penilaian yang dilakukan, guru belum membuat kunci jawaban penilaian berikut rubriknya. Untuk memperbaiki kelemahan tersebut melalui supervisi akademik yang dilakukan kepala sekolah membimbing guru untuk memperbaiki kembali RPP yang disusun.

\section{Siklus II}

Berdasarkan hasil dari siklus satu bahwa masih banyak RPP yang dibuat guru belum sesuai dengan standar penulisan untuk itu peneliti (kepala sekolah) melalui supervisi akademik mengarahkan, membimbing dan memberi contoh guru agar RPP yang disusun diperbaiki sesuai dengan ketentuan. Berdasarkan hasil penilaian pada siklus II terjadi peningkatan pada kualitas RPP guru dimana dapat dilihat pada tabel 3 dibawah ini:

\begin{tabular}{|c|c|c|c|c|}
\hline No & Nilai & Kriteria & Jumlah & Persentase $(\%)$ \\
\hline 1 & $86-100$ & $\mathrm{~A}$ & 10 & 10 \\
\hline 2 & $71-85$ & $\mathrm{~B}$ & 17 & 50 \\
\hline 3 & $56-70$ & $\mathrm{C}$ & 3 & 10 \\
\hline 4 & $<55$ & $\mathrm{D}$ & - & - \\
\hline
\end{tabular}

Berdasarkan tabel 4 di atas 27 dari 30 orang guru atau $90 \%$ sudah menyusun RPP dengan baik, dan rata-rata perolehan nilainya 80,5 .

\section{Pembahasan}

Dari hasil perolehan nilai penyusunan RPP yang dilakukan guru pada siklus 1 dan 2 terdapat peningakatan seperti tergambar dalam table 5 berikut:

Tabel 5 Peningkatan Perolehan Nilai Penyusunan RPP

\begin{tabular}{|c|c|c|c|}
\hline No & Nilai & Siklus 1 & Siklus 2 \\
\hline 1 & $\mathrm{~A}$ & 3 & 10 \\
\hline 2 & $\mathrm{~B}$ & 15 & 17 \\
\hline 3 & $\mathrm{C}$ & 12 & 3 \\
\hline \multirow[t]{2}{*}{4} & $\mathrm{D}$ & - & - \\
\hline & Rata-rata & 70,1 & 80,5 \\
\hline
\end{tabular}

Dari tabel 5 di atas dapat dijelaskan bahwa pada siklus 1 yang telah menyusun RPP dengan baik sebanyak 18 dari 30 orang guru atau $60 \%$ dan pada siklus 2 sebanyak 27 dari 30 orang guru atau $90 \%$. Terdapat peningkatan 30\%. Ditinjau dari perolehan nilain rata-rat pada siklus 1 dengan nilai 70,1 dan pada siklus 2 dengan nilai 80,5 atau terdapat peningakatan 10,4. Berdasarkan kriteria ketuntasan atau kesuksesan penelitian tindakan yang dilaksanakan, maka kegiatan ini dinyataka berhasil atau dengan supervisi akademik yang dilakukan kepala sekolah dapat meningkatkan kemampuan guru dalam menyusun RPP.

\section{KESIMPULAN}

\section{Simpulan}

Berdasarkan hasil penelitian dan pembahasan yang telah dikemukakan, disimpulkan bahwa supervisi akademik yang dilakukan kepala sekolah dapat meningkatkan Kompetensi Guru dalam menyusun Rencana Pelaksanaa Pembelajaran di SMK Negeri 2 Sarolangun provinsi Jambi. Hal ini dilihat dari kesiapan guru dalam pelaksanaan pembelajaran. Disamping itu berdasarkan hasil penilitian yang dilakukan nilai rata-rata RPP yang dibuat oleh guru juga mengalamin peningkatan yaitu pada siklus satu rata-rata nilai 70,1 dan pada siklus dua 80,5.

\section{Saran}

Berdasarkan kesimpulan di atas, maka dapat dikemukakan beberapa saran sebagai berikut: (1) Guru sebagai pendidik yang professional hendaknya selalu meningkatkan kompetensinya dalam melaksanakan tugas termasuk dalam menyusun RPP. (2) Kepala sekolah sebagai seseorang yang bertanggung jawab membinan dan memberikan penilaian kinerja guru 
hendaknya selalu meningkatkan kinerja guru dalam pelaksanaan tugas termasuk dalam menyiapkan RPP.

\section{DAFTAR PUSTAKA}

Arikunto, S. 2010. Prosedur penelitian : Suatu Pendekatan Praktik . (Edisi Revisi). Jakarta : Rineka Cipta.

Kemmis, S dan R. Mc Taggart. (1992). The Action Research Planner. Victoria: Deakin University.

Lestari, T. dan Budiyono, A. 2008. Merencanakan dan Melaksanakan Penelitian Tindakan Sekolah. Bahan Diklat. Jakarta: Dittendik, Ditjen Mutendik Depdiknas. Jakarta: Dittendik, Ditjen Mutendik Depdiknas

Mulyasa. 2011. Menjadi Guru Profesional . Bandung: Remaja Rosdakarya.

Semiawan, Conny, 1985. Bagaimana Cara Membina Guru yang Profesional. Jakarta: Depdikbud.

Sudjana, N. 2008. Profil Kompetensi Pengawas Satuan Pendidikan. Bahan Pelatihan. Jakarta: Dittendik, Ditjen Mutendik Depdiknas

Wiriaatmadja.1999. Penelitian Tindakan dalam Bentuk Penelitian Siklus Sebagai Upaya Meningkatkan Kemahiran Profesional Dosen di Perguruan Tinggi. Jurnal Mimbar Penelitian. No 30/Juli. Sukaresmi. UPI Bandung.

Zuriah. (2003). Penelitian Tindakan dalam Bidang Pendidikan dan Sosial. Malang: Banyu Publishing 